\title{
〔W.P.S.J. の紹介〕
}

\section{W.P.S.J., Vol. 54, No. 3 （1998）〔目次紹介〕}

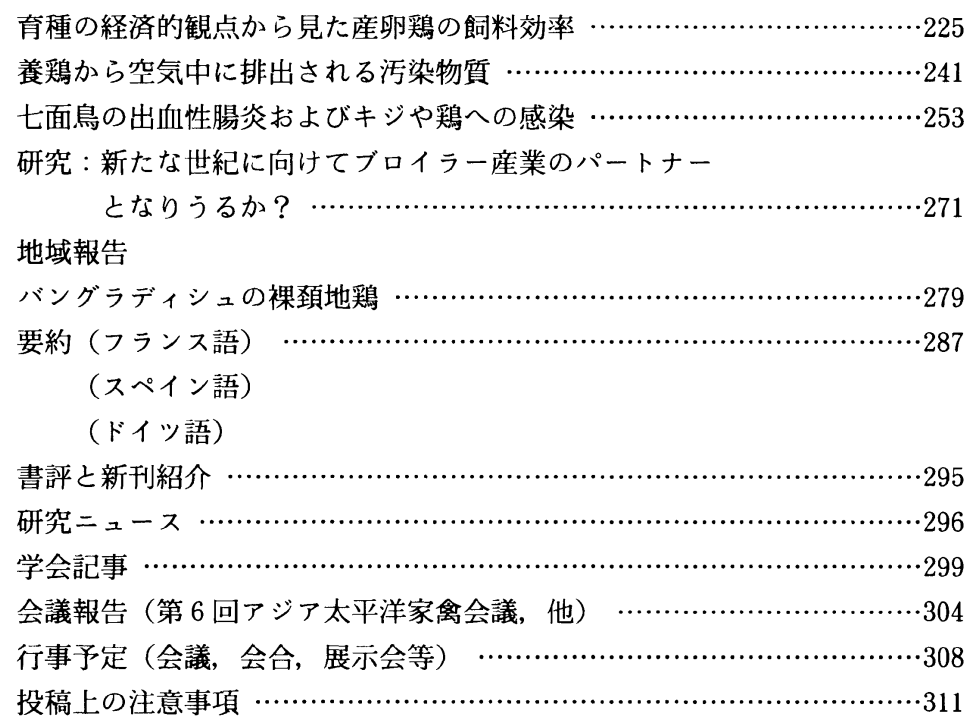

\section{養鴧から空気中に排出される污染物質}

C.M. Wathes : W.P.S.J., 54 (3), 241-251（1998）

\section{序}

空気中に発生する污染物質は, ガス, 粉塵之微生物で ある。これらは，2つの重要な問題である。第一は, 慢性 的にこれらに曝されている鵎や作業者の健康を損ない, 生産性を低下させる。第二はアンモニアや亜酸化窒素の ような土壤の酸性化や地球温暖化の原因となるガスを発 生する。空気感染する病気の伝播の原因でもある。

温熱環境の制御は 1970 年代に技術的に成功した。鶏 舎内で発生する污染物質に対しても同様の成功が必要で ある。制御の目標は, 有害物質の発生を最小限にし, 鶏 や作業者の健康を損なわず, 生産を最適化するという 至って簡単なことであるが，今だ達成されていない。高 密度な養鷄の環境制御は温熱や光制御以上のことを意味 する。すべての環境要因を制御する統合環境制御システ ムが必要である。このシステムは単にサーモスタットで 動く換気扇や断熱鷄舎というものではない。栄養, 環境, 獣医学的な面を包含しなければならない。

本報は, 最近測定された污染物質のデータと生産に影 響する機構を示すとともに, 統合環境制御システムの基 礎を提案するものである。

\section{賈鶏から空気中に排出される污染物質}

鶏舎内の空気は, 鵎, 餌, ふん尿や敷料から発生する 臭気ガスや粉塺, 微生物が渦巻いている。冬季に舎内温 度を維持するために換気量を少なくすると空気中の污染 物質の濃度は高くなる。舎外環境への拡散量は, 鶏舎の 排気口での濃度と換気量による。この点で, 濃度と発生 量は別々に取り扱わなければならない。

污染物質の濃度は, 発生源とシンク間の力学的平衡と みなせる。污染物質の不均一な濃度分布は, 発生源や排 気口の位置に対応しており, 舎内気流パターンによって 修正することができる。このようなわけでブロイラーで は 1〜25 ppm のアンモニアに曝されている。 デンマーク, 英国, ドイッ, オランダの 4 国で, 共通 の測定方法によって粉塵, アンモニアの舎内濃度や発生 量が調べられた。最も高濃度な舎内アンモニア, 粉鹿濃 度, 粉塵発生量はブロイラーであった。ちなみに, アン モ二ア濃度の最高值は英国の $27.1 \mathrm{ppm}$, 吸引性粉塵は英 国の $1.14 \mathrm{mg} / \mathrm{m}^{3}$ であった。また, 最高のアンモニア発生 量は英国の $8294 \mathrm{mg} / \mathrm{h} / 500 \mathrm{~kg}$ (生体重)であった。

英国では畜舎内作業者に対するガスや粉塵の暴露限界 が推奖されている。アンモニアでは, $25 \mathrm{ppm}$ である。し かし，この值は高すぎるという指摘がある。動物に対し ては $20 \mathrm{ppm}$ が推奖されているが, 用量作用の実験から 
出されたものではないので, 今後の研究にきちんとした 值の提示が委ねられる。

空気污染物質の舎内濃度を制御する一つの方法は, 換 気システムであり，これによって濃度を減少させる。鶏 の暴露限界として英国で推奖されている $20 \mathrm{ppm}$ のアン モニア濃度を維持するための最小換気量は，採卵䳕で 240, ブロイラーで $500 \mathrm{~m}^{3} / \mathrm{h} / 500 \mathrm{~kg}$ とされている。これ はすべての条件が定常であり，換気あ完全混合が仮定さ れてのことである。これに従うなら, 䳕を推奖值以上の 濃度に曝してしまうことになる。同様に粉塵を制御する ことも非常に困難である。空気污染物質を換気によって 制御するなら，最小換気量の值は大きくなり，舎外環境 への污染物質の拡散を促進してしまうことになる。

污染物質の発生量は明白に舎内でのプロセスに支配さ れているが, 散逸は, 污染源のまわりの空気の流れに支 配される。農業が污染源である場合の散逸モデルを取り 扱ういくつかの方法がある。最あ簡便な方法は, bulk dilution method であるが, 農場の文地の特性は考慮さ れないので, 精度や有用性は限定されてしまう。

Gaussian plume method は, 英国の環境庁や地方政府 に採用されている。風下側の $1 \mathrm{~km}$ 以上の距離で有効で ある。しかし，建物の近くの後流では不正確である。こ れらの方法は最終的には詳細な気流や散逸モデルに取っ て代わられるであろう。散逸モデルの研究や実スケール の実験が必要である。

\section{空気污染物質が生産に影響するメカニズム}

空気污染物質は呼吸器系の病気を引き起こし, 生産性 の低下をまねく。污染物質特に, 呼吸器の病原体, 呼吸 路の共生微生物とホストである動物間の相互作用を説明 するには以下の 6 つの基本的な仮説が必要である。

1）衛牛的な空気環境のもとでは, 特定の病原体によっ て引き起こされる呼吸器系疾患は減少する。

2）病気でない場合, 污染空気への暴露は鶏の能力を低 下させ, 生理的, 行動的な変化を増加させる。

3）污染空気は病原体を生存, 増殖させることで, 病原 体を有毒なものにする。

4）污染空気は，ホストの共生呼吸器系微生物叢を生 存, 増殖させる。

5）共生呼吸器系微生物叢はホストに対して良性であ る。

6) 特定の呼吸器系病原体は共生呼吸器系微生物叢に対

して生存の能力を高めるように影響しあう。

これらの仮説は，一つの大きな仮説に内包される。それ は, 污染空気に慢性的に暴露されると特定の呼吸器系疾 患の発病率の増加と病気の進行が進む。

鶏においてこの複雑な相互作用は系統的に十分に研究
されていない。Andersonら (1964) と Oyetunde ら (1978) は, アンモニアへの暴露は雊における呼吸器系感 染の感受性を増加させ, 気管粘膜にダメージを与えるこ とを報告した。Reece ら（1980）は, 育雊期のブロイラー で $25 \mathrm{ppm}$ 以上のアンモニア濃度での暴露は成長速度を 阻害することを報告した。同様の効果が $50 \mathrm{ppm}$ 以上の 濃度で育成期に見られた。

多くの鶏の病気は空気感染する。この空気感染を防ぐ ひとつの方法として, 畜舎間の距離を離すことが考えら れる。Goodwin（1985）は，養豚農場間で少なくとも 3.2 $\mathrm{km}$ 離す必要があることを示した。

\section{空気中の污染物質と作業者の健康}

最近英国で, 採卵鶏舎で働く 65 人の作業者に対して 疫学的な検査が行われ, $8 \%$ の呼吸器系疾病の罹患率が 報告された。25\%の作業者は, 前述した暴露限界の濃度 以上の污染空気に曝されていた。鶏舎の粉應は, 気管支 炎, 肺炎, 中毒性の熱病等の原因とされている。污染物 質毎の影響を明らかにすることは現時点で困難である。 とりあえず，マスク等の呼吸器を防護する手だてを行う 必要がある。

\section{鷄舎の空気污染物㑭と環境污染}

鶏舎から発生するアンモニア,メタン,一酸化窒素は, 英国においては環境污染源としては小さい。悪臭は空気 污染物質の第二の分類である。英国では最大許容発生量 の限界量の制限がない。悪臭に対する苦情は 1994 1995 年で 3646 件にのぼった。

\section{空気污染物質の統合的制御}

養鶏を持続させるには空気污染物質を制御する戦略の 開発が必要である。換気によって単に舎外に排出するの ではなく, 舎内外で污染物質が減じられるような制御を 考えなければならない。例えば養豚では植物性油を噴霧 によって粉塵を制御しており, 養哭鳥ではケージから落下 したふん尿を毎週あるいは每日搬出することでアンモ二 ア濃度を低減する成果が報告された。污染物質を舎内外 で制御するには統合的なアプローチが必要である。

Philip ら（1998）は, 英国における養鵎のアンモニア 低減方法についてレビューを報告した。現段階で現実的 な最すよい方法は，1）尿素やタンパク質の排出を減じる ため給餌制御をする，2）鶏舎からの換気による排出空気 を清浄化する, 3) ベルトやふん尿ピットを換気システム を使って乾燥させる，4）敷料の酸化である。彼らは年間 最大 $10 \%$ 低減可能であることを試算した。上記の方法 は温室効果ガスについても有用である。

\section{結論}

鷂舎内で発生する空気污染物質は, 鶏の能力, 作業者 の健康, 環境污染防止のために低減されなければならな 
い。そのためには, 養鶏の収益や持続性の両方を満足さ せる重要な環境要因すべてを統合的に制御するシステム が必要である。この統合的なシステムは従来の工学的な アプローチによる換気や断熱設計以上のもので, 栄養学 的, 環境学的, 獣医学的な側面を持つ必要がある。

(農水省畜試 池口 厚男)

\section{研究 : 新たな世紀に向けてブロイラー産業の パートナーとなりうるか?}

D. Nicholson : W.P.S.J., 54 (3), 271 (1998)

\section{ブロイラーの成長と管理の変化}

10 年前のブロイラー生産者の目的は全鵎が平均して 早く出荷体重となるように飼養管理することであった。 当時, ブロイラーは約 49 日齢で平均生体重 $2 \mathrm{~kg}$ に達 し, 飼料要求率は 2.2 で死亡率は $5 \%$ であった。その後 の成長速度の育種改良によって出荷日齢を 12 日早め, 出荷体重に達するまでに 1 羽当り飼料 $950 \mathrm{~g}$ の節約が期 待されるようになった。

一方, 最近では, 鶏の早熟化や大型化が進み, 腹水症 や脚異常などの疾病発生により育成率が低下する傾向と なっている。ロス種鶏会社では, 現在, 脚や心臟血管の 健康を改善する選抜を行い，良好な結果を生み出しつつ ある。また, 10 年前から出荷体重当りの価格はほとんど 動いていない。したがって, 生産者の収入を高めるため, ブロイラー群における死亡率を抑制することが非常に大 切なこととなっている。さらに，動物福祉の面から英国 では, 1992 年にブロイラーの脚の健康の改善が指摘され た。その結果, ブロイラー生産者は, 早熟で効率の良い 成長を保ちながら育成率を改善するため，ブロイラーの 成長をある程度制限する管理技術に徐々に変更してき た。その基礎となった研究の大部分は過去 10 年のうち に実施されたものであった。

\section{光線プログラム}

歴史的にブロイラーは 24 時間明あるいは 1 時間暗 23 時間明の照明条件下で育成されてきたが, 1980 年代に飼 料効率や脚の健康に有益である間欠照明システムが開発 された。

カナダ西部におけるブロイラーの死亡原因の調査か ら, 脚の異常や骨奇形の発生率が原因の一端であること が明らかとなり，カナダの飼養条件では間欠照明が脚の 健康の改善に有益であることが示された。他の報告で 屯，対照群の死亡率が非常に高いあのの，育成率之脚の 健康の両方において実質的な改善がみられた。しかし， 光線プログラムは腹水症や趾軟骨の発育不全症には有益 な影響を示さなかった。最近，英国の飼養条件下でも同
様の傾向が示された。光線プログラムの技術が現場に導 入されにくい原因の一つは，短日環境下の鶏は捕獲しに くいことである。鷄が活動的になることで脚の健康が改 善されるが, 同時に鶏の捕獲作業は困難となり, 福祉の 問題む発生する。

\section{給䬺プログラム}

ブロイラーの生産現場では，ブロイラーの飼料摂取量 を制限することにより, 飼料要求率を改善し, 育成率を 增加させる試みが行われている。生産見場ではコン ピュータ制御やロードセルを用いて精密に飼養管理され ているため, 制限給餌プログラムの検討は, 研究に比へ て生産の現場で進展してきた。

飼養空間が狭く，換気の不十分なところでは，給餌の 時に起こる一過性の活動上昇が問題となると考えられ る。また，全ての給䭒プログラムでみられる欠点は，種 鶏会社により示された成長が達成されず，制限給餌によ り遺伝的な改善が無効となることである。

\section{全粒小麦の給与技術}

これまで給䭒プログラムの発達と共に全粒小麦の給与 技術が多くの農場で実施されてきた。その目的の一つ は，小麦の製粉コストをゼロとして実質的なコストを節 約することであり，小麦を自家生産しているブロイラー 生産者は大きな利益を得ることになった。全粒小麦の給 与の効果は配合飼料中の栄養素含量や添加される小麦の 量により異なると考えられる。また，消化管内の状態を 改善したり，飼料中のビタミン：ミネラルや抗コクシジ ウム薬の効果を弱めることも考えられる。さらに，屠体 組成に及ぼす影響や選択給餌法との関係など，今後の検 討課題は多い。

\section{研究成果が生産現場に取り入れづらい要因}

生産現場では改善のために新しい考えを取り入れたい という衝動は強いが，生産現場と試験環境では施設面で 大きな隔たりがある。また，飼養密度の違い，主要飼料 原料の違い，経営条件の違いなよ゙样々な要因が試験結果 の現場への導入に関係する。試験条件が生産現場の条件 に適用できることが大切である。

将来

ブロイラー産業の将来を予測することは難しいが，今 後，新規の飼料原料およびそれらに対する酵素添加剤の 開発，小麦の季節や品種の変動原因の解明，ブロイラー 飼養における自由摃取から制限摄取に伴ういくつかの栄 養素要求量の再評価，出荷日齢時重量の制御技術の開 発，出荷日齢の若齢化に伴う効果的なワクチンプログラ ムの開発などを行うことが産業への貢献につながると考 えられる。

（農水省畜試 村上 斉） 